\title{
CAUSES AND EFFECTS OF MARITAL CONFLICT ON EDUCATIONAL AND SOCIAL DEVELOPMENT OF PRIMARY SCHOOL PUPILS IN THE NORTH-WEST ZONE B EDUCATIONAL DISTRICT, BENUE STATE, NIGERIA: TEACHERS PERCEPTION
}

\author{
Rebecca Ashikor Moji ${ }^{1, *}$, Grace Terdoo Waya ljoyah ${ }^{1}$, Joy Ojorumi ljoyah ${ }^{2}$ \\ ${ }^{1}$ Department of Curriculum and Teaching, Benue State University, P.M.B. 102119, Makurdi, \\ Nigeria \\ ${ }^{2}$ Department of Agricultural Education, University of Agriculture, P.M.B. 2373, Makurdi, Nigeria \\ *E-mail address: mikejoy2005@yahoo.com
}

Keywords: marital conflict; development; primary school; pupils; Nigeria

\begin{abstract}
The study investigated the causes and effects of marital conflict, as perceived by teachers, on the educational and social development of pupils in primary schools. A sample size of 400 respondents ( 255 males and 145 females) were drawn from the entire population in the seven local government areas of the district. The survey research design was adopted for the study. The instrument used for data collection was the questionnaire based on Teachers Perception on Marital conflict (TPMCO). The data collected were subjected to mean evaluation, while the chi-square $\left(\mathrm{X}^{2}\right)$ was used to test hypothesis. The findings revealed that $55.0 \%$ of teachers agreed that infidelity was the major cause of marital conflict with the highest mean value of 4.27 , followed by poor communication between couple having $30.5 \%$ of respondents, with a mean value of 3.92 . The deprivation of instructional materials, followed by poor academic performance respectively, with the mean values of 4.82 and 3.94, were perceived by teachers, in order of ranking, as the most serious issues affecting the educational and social development of primary school pupils as a result of marital conflict. Love followed by encouragement were perceived by teachers to be the major ways in improving the educational and social development of pupils from conflict ridden homes. On hypothesis testing, marital conflict significantly $(\mathrm{P} \leq 0.05)$ affected the educational and social development of pupils, thus null hypothesis was rejected, while the alternate hypothesis was accepted.
\end{abstract}

\section{INTRODUCTION}

Shamija and Shamija (2007) defined marriage as a legal union of two people, usually a man and a woman for mutual growth of both. It entails duties and obligations which could be personal, social, emotional and psychological on both the husband and wife. According to Mambula (1999), marriage is a union of two individuals who have unique view point, frame of reference and value. Grungin (2000) stated further that any ceremony be it traditional, religious or legal, formalizing the union of man and woman as husband and wife is termed marriage. Lasswell and Lasswell (1987) point out that marriage is the most important and fundamental human relation for establishing a family relationship and rearing the next generation. It is inevitable that individuals that are involved in ongoing marital relationships will from time to time experience conflict. This is natural since no two individuals are the same, there are bounds to be differences between them.

According to Orhungur (1998), marital conflict is a disagreement which arises in marriage either between the husband and the wife or between relatives of the couple and either of the couple. Mullins (1996) emphasized that marital conflict is not necessarily a bad thing, however, if properly managed, can have potentially positive outcomes.

The National Policy on Education, Federal Republic of Nigeria (2004) clearly states that the primary education given to children aged 6 to 11 years, is the bedrock of the educational system and should be taken very important. Ezeomah et al., (1999) believed that early childhood and primary 
education are important because it inculcates the right type of values, norms, attitudes, skills, etc in children. They also emphasized that the behavior of the child later in life is determined by this level of education. Nnodium (2001) stated that marital conflict put children at risk, thereby laying a devastating base for children's maladjustment at the primary school stage, and influencing their educational and social development. Apart from the home, which serves as the first source of child's socialization, the primary school serves as the secondary source of socialization, and at this level, the child's interaction with the teacher becomes prominent and the role of the teacher as it relates to the child's educational and social development becomes important. Since the children are relatively young and needs guidance, the perception of the teachers at the primary school level on the causes and effects of marital conflict, as well as suggesting ways in improving the educational and social development of the child becomes necessary and of utmost importance. The study therefore aimed at investigating the teachers perception of the causes and effects of marital conflict on the child's educational and social development, particularly at the primary school level, with the objective of identifying ways in improving their socio-academic development.

\section{METHODOLOGY}

The research focused on teachers perception on the causes and effects of marital conflict on the educational and social development of primary school pupils in the North-West zone B educational district of Benue State, Nigeria.

\subsection{Research design, area of study and population}

The survey research design was used for the study. The justification for the use of survey design emanates from the fact that only a representative sample of the entire population was studied and findings generalized to the entire population.

The area of study is the North-West zone B educational district of Benue State, Nigeria, which comprises of seven local governments areas namely, Gboko, Buruku, Tarka, Makurdi, Gwer-East, Gwer-West and Guma, with a total population of one million, five hundred thousand, five hundred and eleven people (Gire, 2007). Research reports noted the zone as area where many homes are conflict ridden, resulting from marital disputes (Orhungur, 1998; Gbenda and Akume, 2002; Gire, 2007).

All the eight hundred and eighty seven government approved primary schools in the district constituted the unit from which the population for this study was drawn. The target population for this study was therefore all the teaching staff located in the educational district.

\subsection{Sample, sampling technique, instrumention and analysis}

A sample size of four hundred respondents (255 males and 145 females) was drawn from six thousand and eighteen teachers across the district using the multi-stage sampling technique to avoid elements of biasness. The instrument for data collection was the questionnaire, based on Teachers Perception on Marital Conflict (TPMCO). The questionnaire had two sections, A and B. Section A contained items that sought information on biodata (personal data) of the respondents, while section B contained items which addressed questions on the causes and effects of marital conflict on the educational and social development of the child and ways in improving the socio-academic level of such a child. The responses to the questionnaire were weighed using the Likert-scale as follows: Strongly Agree (SA), Agree (A), Undecided (U), Disagree (D), Strongly Disagree (SD). The instrument was validated by experts in the area of research, for clarity of expression and to ensure that all the variables of the study are addressed in the instrument. The researcher tested the instrument for reliability by conducting a pilot study using the structured questionnaire. The results obtained from the pilot study were correlated using the Product Moment Correlation Coefficient (r) and a coefficient of 0.81 was obtained, indicating that the questionnaire was reliable to be used. Research assistants were used in the administration of the instrument. They were adequately trained by the researcher as to the correct procedure for collecting data. The mean was used to evaluate data that answers research questions, while the chi-square $\left(\mathrm{X}^{2}\right)$ was used to analyse data to test hypothesis. 


\section{RESULTS AND DISCUSSION}

Research Question 1: What are the teachers perceived causes of marital conflict.

The teachers perception on the causes of marital conflict is given in Table 1. The result showed that $55.0 \%$ of respondents agreed that infidelity is the major cause of marital conflict with a mean value of 4.27 , this was followed by poor communication $(30.5 \%)$ with a mean value of 3.92 . The issue of headship and leadership was the least $(3.8 \%)$ with a mean value of 3.45 . The issue of infidelity topping the least could be linked to cultural factor of the people or lust for materialism. This result agrees with Saxton (1972) who stated that infidelity has been a serious cause of marital conflict been tackled by marriage counsellors and other mediators. This finding also agrees with Kassotis (2002) that $82 \%$ of marital conflicts frequently arises from complaints by one or both spouses in the area of infidelity. Ikyayar (2004) also reported that infidelity has posed a serious threat and is considered a serious cause of marital conflict, largely due to the fact that the trust earlier enjoyed by both parties is abused.

Communication on the other hand is an important tool for married couples, because it is through this, that the couple will know and understand each other better. Olayinka (2000) reported that lack of adequate communication between husband and wife may lead to marriage failure. He further stated that when communication ceases between the husband and wife, in most cases, it is the child that suffers. Issues meant for discussion on the child's welfare are mostly overlooked and this goes a long way in affecting the educational and social development of the child. This finding was supported by Eke (1992) who reported that effective communication between couple enables them to show love, care, concern and acceptance of each other, thus making the marriage a home for other members, especially the children to grow and maximally attain their needs, be it educational and/or social.

Research Question 2: What are the teachers perception, in ranking order, of the effects of marital conflict on educational and social development of primary school pupils.

The perception of teachers, in ranking order, of the effects of marital conflict on educational and social development of primary school pupils is presented in Table 2 . The results showed that $56.3 \%$ of respondents agreed that deprivation of instructional materials is the major effect of marital conflict on educational and social development of primary school pupils with the highest mean value of 4.82. Nnodium (2001) stated that in homes where marital conflict exist, the provision of instructional materials for the child is difficult. The father or mother shift the burden on who provides instructional materials on each other, thereby leaving the child stranded and frustrated. One of the general objectives of primary education in Nigeria as stated by the National Policy on Education Federal Republic of Nigeria (2004) aims at giving the child the opportunities for developing manipulative skills that will enable him to function effectively in the society within the limits of his capacity. The parents have to provide the necessary instructional materials for the child to effectively learn some skills. $32.0 \%$ of respondents agreed that poor academic performance was the second major effect, in order of ranking, with a mean value of 3.94. This could be attributed to the unconducive environment the child is faced with at home. This view agrees with that of Keifer (2007) who reported that a child that grows up where parental affection is not stable enough, be as a result of marital conflict or separation, will not cope effectively with the required concentration for his or her educational development. Emotional response (anger, aggression etc) ranked third in effect with a mean value of 3.82. A child that comes from a family where there is marital conflict could develop some destructive characters such as anger, aggression, fighting, depression etc. Moral behavior is learned through direct observation and imitation. The child therefore observes and is made to understand that quarrelling and fighting are normal ways of life. 
Table 1. Teachers perception on the causes of marital conflict

\begin{tabular}{lcccc}
\hline Causes of marital conflict & $\mathbf{N}$ & $\mathbf{\%}$ & Mean & Standard deviation \\
\hline Infidelity & 220 & 55.0 & 4.2 .7 & 0.830 \\
Poor communication & 122 & 30.5 & 3.92 & 0.904 \\
Inadequate finance & 25 & 6.3 & 3.80 & 0.898 \\
Sexual difficulties & 18 & 4.5 & 3.90 & 0.951 \\
Headship and Leadership & 15 & 3.8 & 3.45 & 1.083 \\
\hline
\end{tabular}

Table 2. Teachers perception, in the ranking order, of the effects of marital conflict on educational and social development of primary school pupils

\begin{tabular}{|c|c|c|c|c|c|}
\hline $\begin{array}{l}\text { Educational and social } \\
\text { development effects }\end{array}$ & Ranking order & $\mathbf{N}$ & $\%$ & Mean & $\begin{array}{l}\text { Standard } \\
\text { deviation }\end{array}$ \\
\hline $\begin{array}{l}\text { Deprivation of } \\
\text { instruction materials }\end{array}$ & (n) & 225 & 56.3 & 4.82 & 0.825 \\
\hline $\begin{array}{l}\text { Poor academic } \\
\text { performance }\end{array}$ & 2 & 128 & 32.0 & 3.94 & 0.923 \\
\hline Emotional response & 3 & 22 & 5.5 & 3.82 & 0.872 \\
\hline Depression & 4 & 15 & 3.8 & 3.72 & 0.882 \\
\hline $\begin{array}{l}\text { Reduction in social } \\
\text { relationship }\end{array}$ & 5 & 10 & 2.5 & 3.60 & 1.053 \\
\hline
\end{tabular}

Research Question 3: What are the teachers suggested ways in improving the educational and social development of primary school pupils from conflict ridden homes.

Teachers suggested ways in improving the educational and social development of primary school pupils from conflict ridden homes, is given in Table 3.

Love was ranked first by $53.8 \%$ of teachers, as the major suggested way in improving the educational and social development of pupils from conflict ridden homes with the highest mean value of 4.13. When the child lacks love and attention, he or she feels very aggressive (Utulu et al., 2004). This might be due to parents and other educators failing in their responsibilities to inculcate the right norms, values and morals in the children. Denga and Denga (2007) also reported that the spirit of love, unity and friendliness must be developed when bringing up children. The second suggested way in improving the educational and social development of pupils, in order of ranking, is the issue of encouragement which was agreed upon by $32.0 \%$ of teachers, with a mean value of 3.75. According to Denga (1986), the parent/caregiver or nursery teacher can encourage children to explore and interact with the environment, manipulating living and non-living objects within it and giving praise for positive acts.

Table 3. Teachers suggested ways in improving the educational and social development of primary school pupils from conflict ridden homes

\begin{tabular}{lcccc}
\hline $\begin{array}{l}\text { Teachers suggested ways in improving } \\
\text { educational and social development of pupils }\end{array}$ & $\mathbf{N}$ & $\mathbf{\%}$ & Mean & $\begin{array}{c}\text { Standard } \\
\text { deviation }\end{array}$ \\
\hline Love & 215 & 53.8 & 4.13 & 0.948 \\
Encouragement & 128 & 32.0 & 3.75 & 0.961 \\
Mutual trust & 24 & 6.0 & 3.52 & 0.984 \\
Greater level of social interaction & 17 & 4.3 & 2.96 & 1.020 \\
Greater attention to academics & 16 & 4.0 & 2.82 & 1.097 \\
\hline
\end{tabular}


Table 4. $\mathrm{X}^{2}$-test on effect of marital conflict on the educational and social development of primary school pupils

\begin{tabular}{cccccc}
\hline Response & $\mathbf{N}$ & $\mathbf{\%}$ & $\mathbf{D f}$ & $\mathbf{X}^{2}$ cal & $\mathbf{X}^{2}$ tab \\
\hline $\begin{array}{c}\text { Educational } \\
\text { development }\end{array}$ & & & & & \\
SD & 20 & 5.0 & & & \\
D & 22 & 5.5 & & & \\
U & 23 & 5.8 & & & \\
A & 207 & 51.8 & & & \\
SA & 128 & 32.0 & 4 & 16.298 & 8.477 \\
\hline Social development & & & & & \\
SD & 17 & 4.3 & & & \\
D & 20 & 5.0 & & & \\
U & 21 & 5.3 & & & \\
A & 209 & 52.3 & & & \\
SA & 133 & 33.3 & 4 & 33.619 & 8.477 \\
\hline
\end{tabular}

$* \mathrm{P} \leq 0.05$

SD: $\quad$ Strongly disagree; $\quad$ D: $\quad$ Disagree

U: Undecided; A: Agree

SA: Strongly agree.

Hypothesis 1: Marital conflict has no significant effect on the educational and social development of primary school pupils.

The results in Table 4 showed that there was significant difference in the mean values recorded on the effect of marital conflict on the educational and social development of primary school pupils. The $X^{2}$ calculated values were higher than the $X^{2}$ tabulated values, indicating significance at $\mathrm{P} \leq 0.05$, thus rejecting the null hypothesis. This result agreed with Ezeomah et al., (1999) who reported that the home is the first agent of socialization for the child, therefore, parents inability to create enabling social and educational environment for children to operate, will to a large extent influence their development negatively at a later stage.

\section{CONCLUSION}

It can be concluded that while infidelity was the major cause of marital conflict as perceived by teachers, the deprivation of instructional materials was ranked highest as the major issue affecting the educational and social development of the child at primary school, as a result of marital conflict. Love followed by encouragement were perceived to be the major ways as suggested by the teachers in improving the educational and social development of the primary school pupils resulting from conflict ridden homes. On hypothesis testing, marital conflict significantly affected the educational and social development of primary school pupils.

\section{RECOMMENDATION}

Though, marital conflict significantly affected the educational and social development of primary school pupils in the North-West zone B educational district of Benue State, Nigeria, however, future study could focus on its effects at both secondary and tertiary school levels. 


\section{References}

[1] Denga, D.I. and Denga, H.M. (2007). Child parenting in developing nations: Challenges and Prospects. Rapid Education Publishers, Calabar, P. 20.

[2] Denga, D.I. (1986). "Marital adjustment and value orientations of selected Nigerian couples: Implication for marriage counseling", The Counsellor, 6(2), 21-26.

[3] Eke, E. (1992). Introduction to educational psychology. Africana Publishers, Ibadan, 73 pp.

[4] Ezeomah, C., Akpan, U. and Oyetunde, T.O. (1999). Innovative approaches to education and human development. LECAPS Ltd., Jos, P. 33.

[5] Gbenda, B.L. and Akume, G. (2002). "Understanding the nature and resolving marital conflict through counseling", The Counsellor, 19, 19-24.

[6] Gire, J. (2007). Social Psychology, Unpublished lecture notes on PSY 207. Department of Psychology, Benue State University, Makurdi, Nigeria.

[7] Grungin, A. (2000). Preparing for marriage. St. Pauls Press, Mumbai, P. 25.

[8] Ikyayar, D.A. (2004). The changing socio-economic role of Tiv women. University Press Ltd., Jos, P. 43.

[9] Kassotis, C. (2002). Resolving marital conflict over money. Retrieved from http://www.redsofts.com.

[10] Keifer, E. (2007). The impact of success and failure on the learner. Pergamon Press, London, P. 26.

[11] Lasswell, M. and Lasswell, P. (1987). Family violence and conflicts. Basic Books, New York, $153 \mathrm{pp}$.

[12] Mambula, M. (1999). The making of a happy and successful family. Challenge Press, Jos, P. 56.

[13] Mullins, L.J. (1996). Management and organizational behavior. Pitman Publishing, London, pp. 62-65.

[14] National Policy on Education (2004). Federal Government Printers, Lagos, 268pp.

[15] Nnodium, M. (2001). "Freedom and growth in marriage" Family Journal, 27(1), 20-26.

[16] Olayinka, M.S. (2000). Sex education and marital guidance. Literarmed Publishers,Ltd., Lagos, P.36.

[17] Orhungur, N. (1998). "The challenges of single parents struggle to overcome the stereotype of broken family: A Nigerian viewpoint", The Counsellor, 16(1), 34-39.

[18] Saxton, L. (1972). The individual, marriage and the family. $3^{\text {rd }}$ Edition, Banks and Cole Publishing Co., California, P. 57.

[19] Shamija, T.A. and Shamija, G.I. (2007). Perspectives in pre-school education in traditional African society. Destiny Ventures, Makurdi, P. 21.

[20] Utulu, R.E., Zaria, L.I., Okwori, A. and Idu, O.O. (2004). Social studies for higher education. Peach Global Publishers, Makurdi, P. 42. 